Confrontation in the form of strong public rhetoric, which led to speculations about possible conflict over Nile water resources has during recent years given way to a spirit of co-operation that is evolving into the Nile Basin Initiative (NBI). While the initiative has made progress, serious challenges that could undermine such co-operation lie ahead.

\title{
Nile Basin Co-operation
}

OPPURTUNITIES AND HURDLES

Dahilon Yassin Mohamoda has a MSc in Development Studies from the London School of Economics and Political Science (LSE). Works for Save the children Norway, Emergency Stand-by Team, and worked earlier at the Centre for Development and the Environment (SUM), University of Oslo, as associated researcher (2003). Related publication: «Nile Basin Cooperation: a review of the literature» Current African Issues 26. Nordic Africa Institute, Uppsala, Sweden, 2003. 
TEXT: Dahilon Yassin Mohamoda

THIS ARTICLE Is an attempt to shed light on the evolving Nile basin co-operative effort and the challenges involved, through discussion of upstream-downstream riparian tension, which is at the centre of Nile politics. The Nile basin covers about Io percent of the area of the African continent, and around 40 percent of its population. ${ }^{1}$ Despite the rich resources of the river, many of the basin countries are characterized by poverty, widespread conflict, environmental degradation, and frequent natural disasters such as drought and famine. The basin is one of the five regions which have been identified as critical regions in the analysis of inter-connections between water, food, poverty, and urbanization. ${ }^{2}$ The river is shared by the following ten countries: Burundi, DR of Congo, Egypt, Eritrea, Ethiopia, Kenya, Rwanda, Sudan, Tanzania and Uganda. The Nile River has two major tributaries: the White Nile and the Blue Nile. The source of the Blue Nile, known as Abbay in Ethiopia, is generally considered to be a small spring at Gishe Abbay located above Lake Tana in northwestern Ethiopia. The Blue Nile, together with Tekeze and Baro-Akobo, which all originate from Ethiopia, contributes about 86 percent of the total volume of Nile water flow. In Sudan, the Tekeze and Baro-Akobo are known as Atbara and Sobat, respectively. The Blue Nile is subject to heavy seasonal fluctuations depending on the rainfall pattern in the Ethiopian highlands.

The White Nile, the longer arm of the Nile, is characterized by a relatively steady flow pattern. The river leaves Lake Victoria, one of the largest freshwater lakes of the world, at Ripon Falls in Uganda (Victoria Nile) and flows through Lake Kyoga and Lake Albert (Albert Nile) into the southern Sudan. It then becomes Bahr el Jebel and joins Bahr el Ghazal around Lake No to form the White Nile. The White Nile heading to Khartoum is joined by Sobat above Malakal city. The flow of the White Nile is slowed down in a marshy area known as Sudd in southern Sudan creating a vast swamp which in turn exposes the water to high evaporation.

At Khartoum, the Blue Nile and the While Nile merge into a single river Nile. At about $320 \mathrm{~km}$ north of Khartoum it is joined by the Atbara/ Tekeze river. The Nile receives no additional water during the rest of its 3,000 km journey through the desert to end up in the Mediterranean Sea.

\section{Background}

The modern history of the Nile basin had been dominated by the British colonial 
power. Terje Tvedt, the historian, who describes the twentieth century as "the most revolutionary period in the river's almost eternal history" gives a detailed account of this era in his recent book «The River Nile in the Age of the British».3

When the British decided to occupy Egypt in I882 its primary aim was to secure the Suez Canal, the water link or the high road to its Indian Empire. It did not take long, however, to realize that the political stability of Egypt, and hence control of the

Ethiopia, the source of the Blue Nile, contributes most water to the Nile, while its utilization is neglible.

Suez Canal and the security of British business interests in Egypt, of the cotton industry in particular, depended much on control of another water source, the river Nile. ${ }^{4}$ In order to promote its imperial interests, the British colonial power controlled the headwaters of the White Nile, occupying many of the downstream countries in the process (Sudan, Uganda, Kenya, and Tanzania), and signed a series of Nile water agreements with different states. ${ }^{5}$ In short London, as Tvedt puts it, "had made the whole majestic river, from its source in the heart of Africa to its outlet at the Mediterranean, a river of the British Empire, and put it under the rule of Queen Victoria”. ${ }^{6}$

The I929 Nile water agreement, concluded by an exchange of letters between the British High Commission in Cairo and the Egyptian government, is one of the key treaties orchestrated by the British colonial power. The agreement, which was designed to benefit Egypt and Sudan, to some extent assigned $48 \mathrm{bcm}$ to Egypt and $4 \mathrm{bcm}$ to Sudan out of an estimated total 84 bcm per year, leaving the difference unallocated. Uganda, Kenya and Tanzania, whose interests were represented by the British, were left out of the allocation, while Ethiopia and other remaining riparian countries were excluded from the agreement.

The agreement reserved the entire flow of the dry season for Egypt, and gave it a right to monitor the flow of Nile Waters in upstream countries. It further guaranteed Egypt a veto right over any construction work on the Nile that would affect the flow of its waters.

Sudan upon independence in ${ }_{1956} 6$ expressed its dissatisfaction with its share of water allocation and called for a revision of the I929 agreement in a manner that would address its demand. Egypt having finalized plans for construction of the Aswan Dam, with its reservoir extending into Sudanese territory, was keen to negotiate an agreement with Sudan. The Aswan Dam was also a major element in the control of the Nile waters for the benefit of the two countries. Negotiations culminated in the I959 Egyptian-Sudanese agreement called Full Utilization of the Nile Waters.?

The I959 treaty, as its name suggests, aimed at "full utilization of the Nile Waters" by sharing all available waters between the two countries, allocating 55.5 billion cubic meters to Egypt and i 8.8 billion cubic meters to Sudan per year as measured at Aswan. The two countries further agreed to develop a unified view in case they had to discuss the treaty with other riparian states that were excluded from this agreement. The treaty also com- 
mitted Sudan to undertake additional reclamation works with the water reclaimed to be allocated equally between the two nations. $^{8}$

Ethiopia immediately protested against its exclusion from the negotiation process, and condemned the agreement, stressing that it had a right to exploit water resources within its borders. The remaining former British colonies, upon their independence in the early ig6os, on different occasions expressed their objection to the I959 bilateral agreement and i929 Nile treaty signed on their behalf. ${ }^{9}$

Several initiatives, from the mid-I96os to the early I990s, have attempted cooperation, focusing on environmental issues. Such attempts include the Hydromet Project (1967), Ungudu (1983), and the Nile Basin Integrated Development (I986). All of these efforts have fallen short of reaching major consensus on utilization of Nile waters, and thus have failed to establish all inclusive basin-wide cooperation. ${ }^{\text {ㅇ }}$

\section{The Nile Basin Initiative}

The Technical Cooperation Committee for the Promotion of the Development and Environmental Protection of the Nile (TECCONILE), established in I993, has played an important role in laying down a foundation for the NBI. It prepared and reviewed the Nile River Basin Action Plan, secured support of donor agencies, and drafted policy guidelines that defined the Shared Vision Program for the Nile basin co-operation. ${ }^{\text {II }}$ The Nile Basin Initiative $(\mathrm{NBI})^{\mathrm{I2}}$ is a result of years of negotiations and re-negotiations among the Nile basin countries. Some of the factors that could have contributed to the initiative include the realization that effective use of the Nile resources requires coordinated effort involving all Nile riparian countries in the face of rapidly increasing population, fast growing irrigation, and consequences of climatic changes; the change in international and regional relations as a consequence of the end of the cold war; regime changes in Uganda (1986), Sudan (I989) and Ethiopia (I99I); and the active engagement of multilateral donor organizations such as the World Bank.

After rounds of negotiations an agreement was reached on a plan of action and on policy guidelines for the establishment of the Nile Basin Initiative, at the 2nd Nile Technical Advisory Committee meeting, held in Arusha in September 1998. An agreed minutes signed at this meeting paved the way for the establishment of the cooperation and five months later, the Nile Basin Initiative was formally launched at an extraordinary meeting of the Nile Basin Council of Ministers in Dar es Salam, Tanzania. In September 1999, the NBI Secretariat which superseded the disbanded TECCONILE, was officially opened in Entebbe. This was a significant development in terms of making progress.

The Nile Council of Ministers is the highest authority of the NBI, and is supported by a Nile Technical Advisory Committee and a Secretariat located in Entebbe. The NBI is guided by a shared vision "to achieve sustainable socio-economic development through the equitable utilization of, and benefit from, the common Nile basin water resources". This shared vision is to be realized through a basin-wide Strategic Action Program that covers eight major projects.

Furthermore, a Subsidiary Action Program has been formulated in order to 
translate the shared vision into reality. The program's main objective is to identify and implement water resource development projects at sub-basin level, involving a limited number of countries. Identified development projects include hydropower development, irrigation and drainage, environmental management, river regulation, drought and flood control, and water use efficiency improvements. The Subsidiary Action Program has been developed on the basis of two distinct sub-basins namely, the Eastern Nile Subsidiary Action Program and the Nile Equatorial Lakes Subsidiary Action Program. The former, which consists of Egypt, Ethiopia, and Sudan, seeks to achieve integrated development of the Eastern Nile region. The latter includes the six countries in the southern portion of the Nile Basin: Burundi, DR of Congo, Kenya, Rwanda, Tanzania and Uganda, as well as Egypt and Sudan. It focuses on two broad program areas, the natural resources management and development of power and trade.

One of the major objectives of the NBI is to establish a set of commonly agreed-upon legal and institutional principles that will guide future basin-wide cooperation. In I995 the NBI, with support from the UNDP, launched a project known as Project $D_{3}$ to serve as a forum to maintain and monitor the legal and political dialogue surrounding Nile water utilization. A "Panel of Experts" composed of three law and water resources experts from each country was established in 1997 and produced, after a series of discussions, a draft text of a Cooperative Framework in early 2000. It aims at providing support in defining an adequate and acceptable framework for co-operation that may pave the way for the equitable and legitimate use of the Nile water resources.

Negotiations are ongoing and agreement has been reached on certain uncontroversial provisions. However, crucial issues such as the status of existing agreements and the relationship between the principles of equitable entitlement and the obligation not to cause significant harm remain unresolved. These issues are at the heart of current conflicts between upstream and downstream states.

\section{Upstream-downstream tension}

Egypt, located at the very end of the river, depends totally on the Nile, while Sudan, which is considered upstream or downstream depending whether its position is viewed vis-à-vis Egypt or against the rest of basin countries, is placed in a unique and at times difficult situation. Sudan's Nile policy is further complicated by the possibility of an independent Southern Sudan as an outcome of a referendum due in 20II. ${ }^{13}$ The remaining riparian countries are located upstream. The riparian states consequently have divergent needs and interests. The upstream-downstream controversy, which is at the heart of Nile basin conflict, and hence the major challenge to basinwide co-operation, can be illustrated well through the uneasy relationship between Egypt and Ethiopia, the two major actors at the centre of Nile politics.

The upstream-downstream tension mainly revolves around the issue of water entitlement or how to share the Nile water resources. Two major principles of the UN Convention on the law of non-navigational use of international watercourses (I997) are central in relation to utilization of shared rivers: the "Equitable and reason- 
able utilization" of shared water resources (Article 5, 6) and the "No significant harm" principle (Article 7) require taking appropriate measures in order to prevent causing significant harm to others. ${ }^{\mathrm{I} 4}$ The downstream states, principally Egypt but also Sudan to some extent, stress the "No significant harm" principle, holding that

\section{ran}

The recent history of the relationship between Egypt and Ethiopia has been characterized by mutual distrust.

upstream riparians may not use shared waters in a way harmful to downstream riparian states. Upstream states, on the other hand, favor the "Equitable and reasonable utilization" rule, stressing the need for equitable utilization of the Nile water resource. The former strive to maintain the status quo, while the latter, being critical of the fact that the downstream riparian states, and Egypt in particular, are the major beneficiaries of the Nile waters, press for a change.

While the convention provides a useful framework to help guide negotiations, it is up to the Nile riparian countries to work out details and reach an agreement on utilization of the Nile waters. Such an agreement remains without doubt the most difficult challenge the Nile basin co-operation has to face.

Egypt, located at the receiving end, contributes almost nothing to the Nile waters and consumes the most. Depending totally on Nile water, the country utilizes much more water than all riparian countries combined. On the other hand Ethiopia, which is the source of the Blue Nile, contributes the most water to the river, while its utilization is negligible. Consequently, the Nile river represents and means different things to the two countries.

The recent history of the relationship between Egypt and Ethiopia has generally been characterized by mutual distrust and at times confrontation. "The only matter that could take Egypt to war again is water" is a frequently quoted statement attributed to the late President Anwar Sadat. The statement was issued in the spring of 1979 just days after signing the historic peace treaty with Israel. It referred to none other than the Nile waters and the message was directed mainly at Ethiopia. A similar statement was made by Boutros Boutros-Ghali, the then Minister of State for Foreign Affairs of Egypt. ${ }^{15}$

The Nile is perceived as Egypt's lifeline, and so it should be underlined that Egypt cannot be imagined without it. This is described best by the repeatedly quoted statement that "Egypt is the gift of the Nile", stated by the Greek Historian Herodotus in $460 \mathrm{BC}$.

The Blue Nile, or Abbay as it is known in Ethiopia, is admired as a mighty river, or father figure (Abbay in Amharic could roughly be translated as "father"), but is also resented, cursed and accused of being a criminal thief or considered even to be a traitor, because it deprives the country of precious fertile soil and water resources year in, year out. The latter description is being shared by more and more people among the young Ethiopian generation. Such a bitter perception is illustrated by Hailu Gabre-Yohannes's poem (in Amharic) about the Blue Nile entitled "Innatkin Belulgn” (I989), which can be translated 
roughly as "insult or curse him on my behalf". He charges the Abbay (Blue Nile) with betrayal of its country and people by flowing freely to feed people in other remote countries, while millions of its own citizens are starving to death due to the lack of a drop of water.

As for the Egyptians, they emphasize the importance of basin-wide cooperation and stress the urgency of such cooperation in light of the serious challenges with which the Nile basin countries are faced, such as rapidly increasing population and environmental degradation affecting the amount

The combination of rapid population growth, economic development, and climate change has intensified the demand for water in the region.

of available waters. The issue of sharing Nile waters is played down and when addressed the focus is on explaining why Egypt's share of Nile water is the largest. The major argument is that Egypt has acquired "historical rights" over Nile waters through usage, international laws and a series of agreements signed with upstream countries at different times. Hence Egypt insists that the colonial treaties are still binding and have to be respected.

At the same time, Egypt, concerned as it is with its strategy of "water security", is full of goodwill regarding general co-operation and regional development and in this sense is very much interested in projects such as ecological conservation, reforestation of the Ethiopian highlands, and other cooperative enterprises aimed at securing more waters. The Ethiopian position, on the other hand, is to accept the principle of regional co-operation, but to focus mainly on what they think Egypt wants to ignore: the redistribution of Nile waters. ${ }^{16}$

The Egyptian and Ethiopian views on Nile basin co-operation are further reflected in various papers presented by the two countries at the semi-official Nile-2002 series of annual conferences. The Egyptians at the 5th "Nile 2002" conference in February I997, for example, urged the riparian countries to promote studies of local water problems and to share this information in order to implement basinwide projects, while the Ethiopian paper presented at the same conference emphasized the need to engage in continuous dialogue with the objective of coming up with an equitable allocation of water resources of the basin. ${ }^{17}$

While the Egyptian government generally welcomes the NBI, in practice it is busy creating new "facts on the ground" to further strengthen its "historical rights". The government has initiated a massive and ambitious irrigation scheme in its western desert, known as the Toshka or the New Valley Project, which will require up to five billion $\mathrm{m} 3$ of Nile water per year, or nearly Io per cent of Egypt's allotment under the I959 agreement. When completed, it will enable the settlement of around 7 million inhabitants in new cities. ${ }^{18}$

The Ethiopian government, on the other hand, has plans to build a large number of micro-dams on the Blue Nile and its tributaries, intended for hydropower production and irrigation schemes. According to the recent study carried out by the Ethiopian Valleys Development Authority, which has estimated a water budget for the period up 
to 2040 , the amount of water needed for development of $\mathrm{I} .2$ million hectares of land found in the Blue Nile, Tekeze, and BaroAkobo basins by means of irrigation is I9 million cubic meters. ${ }^{19}$ This will increase Ethiopia's Nile water usage significantly, and is expected to reduce the amount of water flowing downstream to Sudan and Egypt. As Waterbury and Whittington, who have published widely on water resources, put it:

How Egypt and Ethiopia will defend or promote their interests in the Nile basin has recently become clearer. Egypt will again seek to create "facts on the ground", this time a large new land reclamation and settlement scheme called the New Valley Project. Ethiopia too will create facts by proceeding with water resources development in the Blue Nile basin, including construction of low-cost microdams. ${ }^{20}$

\section{Conclusion: prospects and challenges}

The combination of rapid population growth, economic development, and climate change has intensified the demand for water in the region. According to the UN Population Fund report, the total population of the ten Nile basin countries, which is estimated to be $386,000,000$ at present, is expected to reach $872,000,000$ by the year 2050 . It is estimated for example that Egypt's population, which is 76.9 million at present, will rise to $\mathrm{I} 25.9$ million by the year 2050, while that of Ethiopia, the most populated country in the region, is 8I.2 million at present and is estimated to reach 170.2 million by the year $2050 .^{2 \mathrm{I}}$

While the downstream and upstream countries continue to contest utilization of the Nile waters, the impact of environmen- tal degradation caused mainly by soil erosion and deforestation at the source of the Nile poses a challenge that could have serious consequences on the flow of the Nile in the long term. The historian Zewde G. Sellassie explains that uninterrupted desertification caused by soil erosion and deforestation is expanding at an alarming rate at the major part of the Ethiopian highland areas that are the source of the Blue Nile and its tributaries, exposing millions of inhabitants to drought and famine, and the volume of water flowing to Egypt and Sudan is bound to decrease as a result. ${ }^{22}$ This is indeed an alarming situation that the Nile basin states cannot afford to ignore.

Another challenge is political unrest in the Nile basin. This is mainly due to civil wars in the majority of the basin countries, and it makes the region highly unstable, as well as being an obstacle to basin-wide cooperation. Civil wars in Rwanda, Burundi, DR Congo, Ethiopia, Sudan, and Uganda have remained headline news in the international media for some time and continue to dominate in many of these countries. Tension remains high on the Ethio-Eritrean border, after the two countries fought the bloody I998-2000 war. Many observers are concerned that a crisis in Somalia could spill over to neighbouring countries, thus destabilizing the region.

Another issue which could complicate efforts to establish basin-wide co-operation and eventually jeopardize it if not handled with care, is the unilateral decision to implement development projects in order to promote national interests. Egypt in particular has embarked upon "creating facts on the ground" by undertaking ambitious projects that would have significant consequences in terms of utilization of the Nile 
waters. The more time it takes to reach amicable agreement on fair Nile water distribution, the more other riparian states could be tempted to pursue a similar strategy.

It is very difficult to imagine how the major challenges discussed above could be tackled effectively without a united effort by the Nile basin states. It is equally difficult to expect that such co-operation could be achieved by maintaining the status quo or business-as-usual approach. The NBI is an implicit recognition that the current status quo is no longer sustainable. It is a step in the right direction and provides the Nile riparian states with a unique opportunity to reach agreement, for the first time, on a basin-wide permanent institutional framework.

In September 2008, it will be ten years since the Nile riparian states in Arusha, Tanzania agreed to launch the NBI. The fact that all Nile basin countries, for the first time, have opted to co-operate to face common challenges together is encouraging. A series of high-level, basin-wide meetings and conferences have been conducted, donor agencies have pleaded support, the Shared Vision Projects are operational, and the Subsidiary Action Programs are preparing for the implementation phase. However, although a process that will hopefully lead to a comprehensive basin-wide agreement on utilization of the Nile waters has been initiated, the issue remains unsettled.

The making or breaking of the Nile basin co-operation will very much depend on how the riparian states, and Egypt in particular, tackle negotiations over sharing the resources of the Nile. While progress has been made, the initiative has yet to pass the most crucial test of reaching agreement on a fair distribution of the water resources, if it is to be transformed from the current temporary arrangement into a permanent institution of basin-wide cooperation.

\section{$\cdot f \cdot$}

I "Basin" refers to the entire geographical area drained by a river and its tributaries.

2 Vakkilainen, P.; Varis O., I999. "Will Water Be Enough, Will Food Be Enough?”, technical document in Hydrology IHP-V 24, Paris: UNESCO; Varis, Olli, I998a. "Water and Third World Cities: The Expanding Puzzle”, Research in Progress PIP I6, Helsinki: United Nations University/World Institute for Development Economics Research.

3 Tvedt, Terje, 2004:I. "The River Nile in the age of the British: political ecology and the quest for economic power". London. I.B. Tauris.

4 Tvedt, Terje, 2004: chapter one. Tvedt in chapter seven of the same book further elaborates how the British later planned to "strangle" Nasser's Egypt by means of the Nile waters during the Suez crisis.

5 Agreements the British signed include: the Anglo-Italian Protocol of April I5/I89I, the Ethio-British Agreement of May I5/I902, the agreement of December I3/ I906 between Britain, France and Italy, the December I4-20, I906 agreement between Britain and Italy, and the May 7/1929 agreement between Britain (on behalf of Sudan, Uganda, Kenya, and Tanzania) and Egypt. All these agreements had a single objective: that of safeguarding British colonial interests in Egypt, and therefore favoured Egyptian Nile interests.

6 Tvedt, Terje, 2004:I9. "The River Nile in the age of the British : political ecology and the quest for economic power". London. I.B. Tauris.

7 The agreement was signed immediately after Egypt's friendly government, through a coup, came to power in Sudan.

8 A joint effort by Egypt and Sudan to construct the Jonglei Canal, which fell victim to the civil war in the south, is a major case in this regard.

9 Some Kenyan and Ugandan parliamentarians recently have further pushed for a public denunciation of the colonial treaties, which they characterize as unjust, and called for compensation by Egypt for its previous "monopolized" utilization of the Nile water. Chege, Mbitiru. "Egypt May Soon Loose Control Over Nile Waters" in The Nation, Nairobi, I6. February 2004.

IO Refer for details on earlier attempts for cooperation to, Arsano, Yacob, 2006. "The Nile Basin: Predicaments of Upstream-Downstream Cooperation: Prospects For 2Ist Century" in Terje Tvedt and Richard Coopey (eds): A history of Water: the political economy of water Volume II (History of Water), London: Tauris. 
II The TECCONILE further initiated and organized a semiofficial series of annual conferences, better known as "The Nile 2002 Conferences", which brought together scholars and technical experts, facilitated exchange of views and assisted policy makers to explore possibilities of basin-wide co-operation.

I2 More details on the Nile basin Initiative home page: www.nilebasin.org.

I3 Such a scenario will mean one additional regional competitor for the precious waters of the Nile, to mention just one consequence.

I4 United Nations, I997. "UN Convention on the Law of Non-navigational Uses of International Watercourses". Full text available at: http://www.un.org/ga/documents /gares5I/ga5I-229.htm

I5 Timberlake, L., I985:I85. Africa Crisis. London: International Institute for Environmental and Development.

I6 Erlich, Haggai, 2002:218. The Cross and the River: Ethiopia, Egypt, and the Nile. Boulder, Colo: Lynne Rienner.

I7 Erlich, Haggai, 2002:219-I9.

I8 Kerisel, Jean, 200ı:Chapter 5. The Nile and its Masters: Past, present, future - Source of hope and anger. Brookfield, VT: A. A. Balkema.

I9 Zewde Gabre-Sellassie, 2006:29. "The Blue Nile and its basins: an issue of international concern". Addis Ababa, Forum for Social Studies, IGTK consultation paper series.

20 Waterbury, John; Whittington, Dale, I998:I50. "Playing Chicken on the Nile: The Implications of Micro-dam Development in the Ethiopian Highlands and Egypt's New Valley Project" in Natural Resources Forum, Vol. 22, No. 3:155-64.

2I State of World Population 2007. United Nations Population Fund: http://www.unfpa.org/swp/

22 Zewde Gabre-Sellassie, 2006:3I. 